Rajko M. Bukvić1

Association Srpski krivak,

Belgrade, Serbia
ORIGINAL SCIENTIFIC ARTICLE doi: 10.5937/ekonomika2002017B

Received: April, 01. 2019.

Accepted: May, 14. 2020.

\title{
CONCENTRATION AND COMPETITION IN SERBIAN BANKING SECTOR IN THE PERIOD 2016-2018
}

\begin{abstract}
The paper deals with the analysis of the degree of concentration and competition in Serbian banking sector in the period 2016-2018. The analyses are based on the data of bank financial statements for relevant years, as well the results of other researchers and reports of the National Bank of Serbia. It was used the traditional concentration indicators (CRn and HH indices), as well as the Gini coefficients and not only in Serbia the relatively rarely used Linda indices. The concentration degree in all cases is calculated based on five variables: total assets, deposits, capital, bank operating income and loans. Although these variables are highly correlated, the results show relative important differences. In the case of such variable as capital, the Linda indices suggested the existence of the oligopoly structure. As conclusion, it was demonstrated that in the case of the relatively large number of banks in Serbia, the existing concentration degree is generally moderate low, which provides suitable conditions for the development of healthy competition among them.
\end{abstract}

Key Words: concentration, competition, banking sector, SCP paradigm, Serbia, indices Linda, Gini coefficient, Herfindahl-Hirschman index, Lorenz curve, concentration ratio, oligopoly

JEL classification: C38, G21, L10

\section{КОНЦЕНТРАЦИЈА И КОНКУРЕНЦИЈА У БАНКОВНОМ СЕКТОРУ СРБИЈЕ У ПЕРИОДУ 2016-2018}

\begin{abstract}
Апстракт
Чланак се бави анализом степена концентрације и конкуренције у банковном сектору Србије у периоду 2016-2018. Анализе су засноване на подацима из финансијских извештаја банака за одговарајуће године, као и других истраживана и извештаја Народне банке Србије. Коришћени су традииионални показатељи кониентрације (CRn и НН индекси), као и Ђинијев коефицијент и не само у Србији релативно ретко коришћени индекси Линда. Степен концентрачије у свим случајевима обрачунат је за пет променљивих: укупна актива, депозити, капитал, пословни приход и кредити. Иако су ове променљиве високо корелисане, резултати показују релативно значајне разлике. У случају капитала као променљиве, Линда индекси сугеришу постојање олигополске
\end{abstract}

${ }^{1}$ r.bukvic@mail.ru, ORCID ID 0000-0001-6744-3912 
структуре. Као закључак, показано је да је у условима постојања релативно великог броја банака у Србији постојећи степен концентрације умерен, ито даје добре услове за развој здраве конкуренције између њих.

Кључне речи: концентрација, конкуренција, банковни сектор, СПР парадигма, Србија, индекси Линда, Ђинијев коефицијент, Херфиндал-Хириманов коефицијент, Лоренциова крива, стопа концентращије, олигопол

The last few decades have seen considerable attention being put towards the analysis of development of market competition and affirmation of market principles. This coincided with the collapse of planned economies and the beginning of their transformation into market economies. In emerging market economies one of the most important problems was the building new, market oriented financial system, with new role of the financial and bank institutions. As a result, the question of the evolution of the financial system which having been, and still remaining, outside the mainstream neo-classical modelling, has come to the top of research work [Rybczynski 1997]. Consequently, considerations of the conditions for the building the market circumstances are characteristics not only in so called real economy sector but in other branches, as well. Among these other branches, which are infrastructural both on a state level and for the international economy, the banking sector is of particular interest. Its importance has been growing not only in the countries of the former socialist world, which is related with the hugely increased role of market and the consequent deregulation in this and other sectors, but also in developed countries, where deregulation and liberalization processes have also taken place, followed by an integration (mergers and acquisitions) of banks. At the same time, the developed financial markets, especially the European ones, have become more market-oriented (Rajan \& Zingales, 2003).

In modern economic theory it is assumed that in order to create an efficient market system in all economy segments, especially in the banking sector, it is necessary to provide a competitive environment. It is argued that the potential benefits of competition in banking are similar to its benefits for other industries, such as: it can improve allocative, productive, and dynamic efficiencies (by promoting innovation, e.g.), with the ultimate benefit being stronger economic growth (Northcott, 2004). However, the authors in last few decades emphasized not only benefits, but also the negative effects of the banking competition. We will not focus specifically on this issue, and will instead use this overview created by Moiseev (see Table 1, slightly modified).

Table 1. Positive and negative effects of the banking competition

\begin{tabular}{|l|l|l|}
\hline Author(s) & Year & Effects of banking competition: Conclusion \\
\hline Petersen M. and Rajan R. & 1995 & $\begin{array}{l}\text { In highly-concentrated markets, small-business loans } \\
\text { are more accessible, and in addition to that, new } \\
\text { companies can take out loans with lower interest rates. }\end{array}$ \\
\hline Jayaratne J. and Strahan P. & 1996 & $\begin{array}{l}\text { Salaries and production grow faster after new bank } \\
\text { branches can open unrestrained, therefore we can } \\
\text { conclude that banking competition has a positive effect } \\
\text { on the economic growth. }\end{array}$ \\
\hline
\end{tabular}




\begin{tabular}{|l|l|l|}
\hline Shaffer S. & 1998 & $\begin{array}{l}\text { Household income grows faster in areas with a larger } \\
\text { number of banks. }\end{array}$ \\
\hline Black S. and Strahan P.* & 2000 & $\begin{array}{l}\text { The number of new companies and business } \\
\text { associations is smaller in areas with higher market } \\
\text { concentration. }\end{array}$ \\
\hline Collender R. and Shaffer S. & 2000 & $\begin{array}{l}\text { While the effect of market concentration on household } \\
\text { income between 1973 and 1984 was negative, it } \\
\text { became positive between 1984 and 1996. }\end{array}$ \\
\hline $\begin{array}{l}\text { Bonaccorsi D. and } \\
\text { Dell'Ariccia G.* }\end{array}$ & 2000 & $\begin{array}{l}\text { The start-up scene is more active in markets with a } \\
\text { concentrated banking sector. }\end{array}$ \\
\hline
\end{tabular}

* Mimeo, used by Moiseev.

Source: (Moiseev, 2008, p. 104)

Competition in the banking sector is one of the forms of market competition. It appeared lather than competition in industry, but it is characterized by a high intensity and a great diversity of forms and methods. The main characteristics of the bank competition are described in detail in (Коробова, 2006, pp. 76-100).

\section{The development of modern banking sector in serbia}

The development of market economy and the affirmation of market business principles are some of the main tasks in all countries in transition, including Serbia. In addition to the efforts of the lawmakers and the economic policy creators, this task is reflected in theoretical and practical interest of the academia, where a growing number of scientific papers in different scientific journals tackle different related issues. Unlike other so-called socialist countries, in Serbia, i.e. Yugoslavia, the problems tied to the creation of market relations were not unknown starting from the 1950's, however this country still started this process significantly later than those countries due to the circumstances in which it found itself at the time. Regardless of some not insignificant controversies in regards to the character of the current socialist market relations, the decade long experience of its existence and effects was not adequately evaluated and it was not utilized in the current conditions. Instead, the principle of "not saying the obvious" was adopted and present in the documents of the highest international organizations. Alternatively a demeaning approach was adopted. The effect of this on the overall results is probably yet to be fully understood, but that issue is not the object of research in this paper. It is, in fact, a mere base for the conclusion that Serbia entered the transition process without considering and valuing its past experience.

The said observation certainly had an effect on the reforms and the development of the banking system. Although banks had until then been treated as a "service of the economy", with a strong influence of the political establishment, banks as well as other branches of economy did know the market principles and were in part exposed to them. But in this case also, the previous experience was not considered. After the political changes that took place in 2000, the Serbian banking sector has also undergone some great and significant changes. At the beginning of 2001, a total of 86 banks operated on the territory of Serbia, but during the same year, 23 lost their licenses, which combined 
with some other changes lowered the number of banks to 49 at the end of the year (Bankarski sektor SRJ 31.12.2001.g., 2000, 1-2). Right at the beginning of 2002, four major banks underwent bankruptcy proceedings (Beobanka AD Beograd, Beogradska banka AD Beograd, Investbanka AD Beograd and Jugobanka AD Beograd), and their share in the total bank assets was over $57 \%$.

In the following years, changes continued to take place: the once biggest banks ceased to exist (they were liquidated), some foreign banks entered the market, there were a few acquisitions, etc. All in all, we can notice that there is a decreasing trend in the number of banks, usually through acquisition and merger processes, and only exceptionally because the National Bank of Serbia stripped them of operating licenses. At the same time, foreign capital continued penetrating into the banking sector, especially stimulated in 2001, when five foreign banks obtained license by the National Bank of Yugoslavia: Micro finance banka AD Beograd, Raiffeisenbank Jugoslavija AD Beograd, Alpha bank AE (Beogradska afilijacija), HVB banka Jugoslavija AD Beograd i National bank of Greece (filijala Beograd). At the end of 2018, there were 27 banks in the market, none of them having a significantly bigger share in the market. For small countries like Serbia, it is a considerable number, and it provides for a development of competition. Foreign banks entering the market and the processes of deregulation and liberalization have naturally created a tougher competition in the banking market. However, there are seemingly no serious and consequent analyses of competition in the market in question. The competition in this sector has not been of particular interest of researchers in the past, although Serbia (Yugoslavia) has had, unlike other socialist countries, considerably developed market relationships, at least in the real sector. Therefore, the most extensive and comprehensive monograph [Begović et al. 2002] does not consider the competition in this sector.
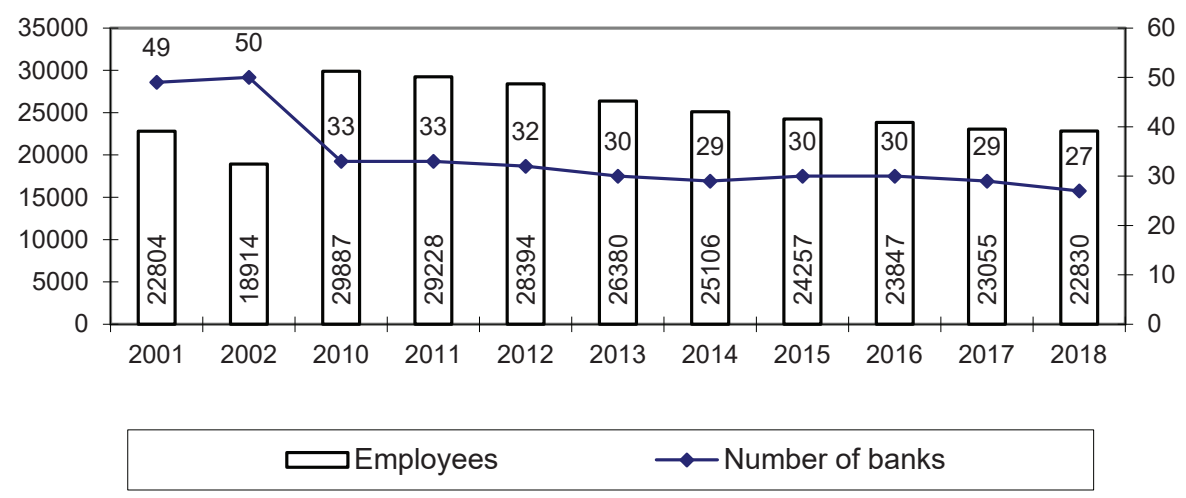

Figure 1. Number of banks and employees in the Serbian banking sector 2010-2018 Source: Банкарски сектор 2002, Banking Sector in Serbia. Quarterly Report. (2010-2019)

The number of banks and employees in banking sector in the period between 2010 and 2018 is shown on the figure $1 .^{2}$ Both the bank and employee figures have

${ }^{2}$ In October 2018 the Direktna banka integrated the Piraeus Bank, so the number of banks further 
decreased substantially in the present decade, by more than $10 \%$ and $20 \%$ respectively. However, both figures are still considerable for the relatively small financial market of Serbia. According to Quarterly Report for the $4^{\text {rd }}$ quarter 2018, out of the total number of banks, 7 are domestic while 20 are foreign. The domestic - foreign ratio in total assets is 24.5:75.5, and in capital it is 24.1:75.9. The total number of business units (all forms of business network parts: corporate offices, banking subsidiaries, branch offices, counters and other business units) amounts to 1,598. The total number of business units also decreased in previous years. It amounted 1,719 at the end of 2016 and 1,627 at the end of 2017.

\section{Methodological considerations}

Competition in general and especially in the banking sector, is a complex process difficult to measure, since there is no generally accepted or best approach to measuring it, nor is there a unit indicator. Therefore, different approaches have been developed in order to measure the degree of competition in a market. They can be divided into direct and indirect approaches. Direct approaches are based on the degree of market power, as the source of addition to the market price. The direct estimation assumes the existence of data about bank service prices and their marginal costs, which is often lacking. In those cases, we use the indirect estimation method, which can be structural and nonstructural. The first one is based on the paradigm "structure - behavior - result", first published by Edward Chamberlin and Joan Robinson in 1933 and Mason in 1939, and suggests using the market concentration degree to measure the degree of competition. The structure-conduct-performance (S-C-P) paradigm, also known as the Bain/Mason paradigm or concept, has been a very popular model in industrial economics since the Second World War. It is largely empirical, i.e. it relies on empirical data but for the most part, lacks a theoretical base. ${ }^{2}$ Of course, the $\mathrm{S}-\mathrm{C}-\mathrm{P}$ is not originally developed for banks. But, applied to this sector, S-C-P paradigm means a change in the market structure or concentration of banking firms affects the way banks behave and perform:

$$
\text { Structure } \rightarrow \text { Conduct (higher prices) } \rightarrow \text { Performance (higher profits) }
$$

assuming that a concentrated market allows firms to set prices (e.g. relatively low deposit rates, high loan rates) which boost profitability, i.e. bank profit rate.

In opposite to S-C-P approach, the Relative Efficiency Hypothesis (RE) assume that some firms are enormous profitable because they are more efficient than others. In other words, efficiency is exogenous. The hypothesis states that the causality goes from greater efficiency, lower prices and higher concentration/market share:

Efficiency $\rightarrow$ Conduct (Higher Output and/or Lower Prices) $\rightarrow$ Market Share $\rightarrow$ Performance (Higher Profits)

and can be linked to the X-efficiency (hypothesis): some firms have superior management or production technology, which makes them relatively more cost X-efficient with lower costs.

The nonstructural estimation denies the correlation between concentration and competition, especially in systems with low entry and exit costs (contestable markets),

decreased to 27. 
see (Baumol, 1982). Within this approach many models examine the relationships between banks performances depending on different exogenous factors (models PanzarRosse, Boone and others).

The Structure-Conduct-Performance (S-C-P) paradigm dominated industrial organization studies until the early 1970s. But, researches in banking sector generally not approved the main $\mathrm{S}-\mathrm{C}-\mathrm{P}$ hypothesis, i.e. the structure (market shares) was in many empirical investigations not correlated with profitability of banks. In fact, in our case, for 2018, the simple correlation coefficient between rate of profit (profit/total assets) and market share was small - only 0.2469. Such result, of course, is not surprise, see for example (Smirlock, 1985, p. 70).

Although we do not identify competition with concentration, our approach can formally be considered as structural. As this research is one of the first steps in competition analysis of the banking sector in Serbia is, we will not apply this approach. After all, concentration coefficients also can be used in the nonstructural approach. We can define concentration as it is defined in the OECD Glossary: "Concentration refers to the extent to which a small number of firms or enterprises account for a large proportion of economic activity such as total sales, assets or employment" (Khemani \& Shapiro, 1993), without considering different contexts, which are observed by the Glossary.

Before carrying out an appropriate empirical analysis, some issues are to be resolved. First of them concerns the variables relative to banks and its business that are to be used. While in the case of manufacture and other branches in real economy sector this issue is less or more solved, the situation is different in the banking sector: variables such as volume of production or sales cannot be used. Therefore, other indicators are necessary. They can be, for instance, attracting deposits (Berger \& Hannan, 1989), assets (Маринковић, 2007) assets and deposits (Berger et al., 1999), assets, loans and deposits (Vuković, 2006), (Ljumović et al., 2014) and (Alihodžić, 2019), total assets, net interest income and capital (Eraković, 2017), deposits and loans to legal and physical persons (Коцофана и Стажкова, 2011), deposits, loans to legal and physical persons and assets (Ракша, 2010), deposits, loans to legal and physical persons and capital (Lončar \& Rajić, 2012), assets, capital, loans, deposits, interest income and net profit (loss) after tax (Miljković et al., 2013). ${ }^{3}$ Finally, National Bank of Serbia's regular quarterly reports (Банкарски сектор у Србији. Квартални извештај, 2010-2018) give short surveys of concentration and competition in the banking sector, using nine financial balance variables: assets, loans (total), loans to population, loans to companies, deposits (total), deposits of population, income (total), interest income, income from fees and commissions. As we can notice, the most frequently used variable is total assets, although its use does not exclude other variables. We will also not limit our research to using only variable, therefore we have chosen five indicators: total assets (X1), deposits (X2), capital (X3), operating income (X4) and loans (X5). The choice is due not only to theoretical reasons, but also to the sources accessible to the author: bank financial statements available on the website of National Bank of Serbia (Биланс стања/успеха банака, 2018). In this paper we will analyze the data from the balances of Serbian banks for the year 2016-2018, but in certain cases we will refer to works pertaining to the previous years.

Although the problem of the choice of variables seems of great importance, the data we analyzed show that this is not so. The correlations between the selected 
indicators (see Table 2) are very high, and differences practically negligible. Smallest are the coefficients between capital and other variables, that can be explained with the nature of capital as the residual variable, as we will see in further.

Table 2. Correlation coefficients for the selected variables X1-X5 in 2016 and 2018

\begin{tabular}{|l|c|c|c|c|c|c|c|c|}
\hline Year & \multicolumn{4}{|c|}{2016} & \multicolumn{4}{c|}{2018} \\
\hline Variable & $\begin{array}{c}\text { Deposits } \\
\text { (X2) }\end{array}$ & $\begin{array}{c}\text { Capital } \\
\text { (X3) }\end{array}$ & $\begin{array}{c}\text { Operating } \\
\text { income } \\
\text { (X4) }\end{array}$ & $\begin{array}{c}\text { Loans } \\
\text { (X5) }\end{array}$ & $\begin{array}{c}\text { Deposits } \\
\text { (X2) }\end{array}$ & $\begin{array}{c}\text { Capital } \\
\text { (X3) }\end{array}$ & $\begin{array}{c}\text { Operating } \\
\text { income } \\
\text { (X4) }\end{array}$ & $\begin{array}{c}\text { Loans } \\
\text { (X5) }\end{array}$ \\
\hline Total assets (X1) & 0.9975 & 0.9548 & 0.9923 & 0.9807 & 0.9979 & 0.9516 & 0.9894 & 0.9652 \\
\hline Deposits (X2) & & 0.9327 & 0.9910 & 0.9720 & & 0.9315 & 0.9856 & 0.9551 \\
\hline Capital (X3) & & & 0.9432 & 0.9549 & & & 0.9470 & 0.9437 \\
\hline Operating income (X4) & & & & 0.9719 & & & & 0.9679 \\
\hline
\end{tabular}

Source: Calculated on basis of Financial Statements, http://www.nbs.rs/internet/cirilica/50/50_5.html

The second methodological question is the choice of concentration indicators (index). Among the many indicators, see for instance (Martić, 1986), two have been used by researchers and by the practical antimonopoly policy: coefficients of concentration, or concentration ratios $\mathrm{CRn}$ (the share of $\mathrm{n}$ largest companies in a certain market, where $\mathrm{n}$ mostly stood for 4) and HH index (Herfindahl-Hirschman index, or simply Herfindahl index, the sum of the squares of the shares of all participants' in a market). Both indices are based on individual company shares in a market

(3) $s_{i}=\frac{Q_{i}}{Q}$

where: $\mathrm{Qi}=$ volume of company production $\mathrm{i}, \mathrm{Q}=$ total production volume in an industry branch. Instead of the volume of production, other variables can be used, as it often occurs even in analyses within the real economy sector, for example income or company assets etc. Coefficients CRn are defined as the sum of $\mathrm{n}$ greatest shares, as follows:

(4) $C R n=s_{1}+s_{2}+\cdots+s_{n}=\sum_{i=1}^{n} s_{i}$

and coefficients (indices) $\mathrm{HH}$ as the sum of share squares of all participants in a market:

(5) $I_{H H}=\sum_{i=1}^{m}\left(s_{i}\right)^{2}$

We will also use these indices. But, unlike the mentioned work (Ljumović et al., 2014), where were used indices CR4 and CR8, we will use also index CR3. We consider, and this has been demonstrated on multiple occasions, that index CR8 is too high for Serbia, and therefore considered insignificant for the purpose of our work. It is therefore strange that the National Bank of Serbia uses it in its reports, along with CR5 index and CR10 index, which is even less significant than CR8.

The advantages and disadvantages of the indicators (3) and (4) in literature are well described, see for example (Буквич, 2015). In addition to the mentioned indices (coefficients), we will also use the Gini-coefficient, another commonly used method to determine concentration degrees. In a multitude of ways to determine this coefficient, we have opted for the following (Lipczynski et al., 2017, 278): 
(6) $G=\frac{\sum_{n=1}^{N} \sum_{i-1}^{n} s_{i}}{0.5(1+N) \sum_{i=1}^{N} s_{i}}-1$

where $\mathrm{s}_{\mathrm{i}}$ indicate shares (3), and $\mathrm{N}$ is the number of observed units (in this case banks). This formula is inverse in comparison with the usual ways to present and calculate the Lorenz curve and the Gini-coefficient, as it organizes the sequence into a decreasing one, resulting in a graphic depiction double symetrical when compared to a Lorenz curve - diagonally from (0.0) to (1.1) and vertically.

We determined in our calculations both of these indicators (4) and (5), see Table 3 . In addition to that, considering their disadvantages, we choose one more index not yet used in Serbian literature ${ }^{4}$, but also rarely used in other countries, especially in the so-called transition economies. One of the examples of its uses (Коцофана и Стажкова, 2011) refers to the banking sector (in Russia). This index (more precisely, the system of indices) is calculated by following general formula, which is developed into a specific formula for every value of $\mathrm{m}$ :

(7) $I L_{m}=\frac{1}{m(m-1)} \sum_{i=1}^{m-1} \frac{m-i}{i} \cdot \frac{C R i}{C R m-C R i}$

This index was constructed by the EU Commission consultant Rémo Linda (Linda, 1976). As well as the index CRn, it is only calculated in case of the few (m) largest enterprises and, therefore, also analyzes the "nucleus" but not the "periphery" of the market in question. However, unlike the concentration ratio CRn, Linda-index (L-index) focuses on the differences in the market "nucleus". In other words, the L-index has to be considered in combination with the concentration-ratio, it measures the "oligopolistic equilibrium" by giving information about the relative shares and their evolution of the top-firms. We have already showed the advantages of the use of Linda-indices in (Буквич, 2013), although this article was primarily illustrative. The calculations of this index are alternate and demanding. Of course, the use of personal computers renders the last note insignificant.

In (Ljumović et al., 2014), (Lončar \& Rajić, 2012) and (Miljković et al., 2013) Linda-index was not used, but $\mathrm{CRn}, \mathrm{HH}$ and others were: reciprocity index, comprehensive concentration index or Horvath-index (CCI), Entropy-index (E-index) and Ginicoefficient. For our purposes, all other indices except the CRn index bear no importance. In his $\mathrm{PhD}$ thesis, M. Kostic (Костић, 2013) gave an overview of concentration indices, however his analyses did not refer to the banking sector but to oil and beer markets.

\section{Concentration and competition in serbian banking sector}

Unlike some empirical researches, which divide the banking sector into small, middle and large banks, see for example (Bikker \& Haaf, 2002a), we will consider the whole sector as one set. Clearly, it doesn't mean that in a theoretical sense we prefer such approach. The main reason for our choice is obvious enough: regardless of the relatively large number of banks, the banking and financial markets in Serbia are small, by all relevant indicators: total bank assets at the end of 2018 amounted to 3,774,055,499 thousand dinars, while the capital equaled to $676,704,699$ thousand dinars (i.e. $31,930,862$ and 5,725,344 thousand euros, by exchange rate of 1 euro $=118.1687$ dinars). Therefore, for this work purposes we don't find this division useful by any criteria. 
This paper can be considered as a continuation of our research of the concentration and market structures in modern Serbian banking sector. In previous works we analyzed the status in this sector in 2016 (Bukvić, 2017) and 2017 (Bukvić 2019). But, recent work is not only renewed with data and analysis for 2018. We have made some new calculations by using indicators that there were not used and some other considerations, that make possible the better observation of the bank concentration by used variables.

Table 3. Concentration indices in Serbian banking sector in 2016-2018

\begin{tabular}{|l|c|c|c|c|c|c|c|c|c|c|c|c|c|}
\hline Criterion & \multicolumn{3}{|c|}{ CR3 } & \multicolumn{3}{c|}{ CR4 } & \multicolumn{3}{c|}{ CR8 } & \multicolumn{3}{c|}{ HH } \\
\hline & 2016 & 2017 & 2018 & 2016 & 2017 & 2018 & 2016 & 2017 & 2018 & 2016 & 2017 & 2018 \\
\hline Total assets & 39.6 & 38.5 & 37.4 & 47.4 & 47.0 & 45.8 & 69.4 & 70.6 & 70.1 & 813 & 813 & 779 \\
\hline $\begin{array}{l}\text { Deposits and other } \\
\text { liabilities }\end{array}$ & 40.1 & 38.8 & 37.6 & 47.9 & 47.7 & 45.9 & 69.7 & 71.0 & 70.9 & 819 & 818 & 786 \\
\hline Capital & 38.7 & 37.7 & 37.2 & 47.4 & 46.9 & 45.8 & 73.6 & 73.3 & 72.3 & 882 & 848 & 807 \\
\hline Operating income & 36.8 & 34.8 & 37.0 & 44.6 & 43.4 & 46.2 & 67.9 & 69.0 & 70.2 & 764 & 762 & 805 \\
\hline $\begin{array}{l}\text { Loans and } \\
\text { receivables }\end{array}$ & 36.9 & 37.5 & 37.3 & 45.3 & 46.2 & 45.1 & 67.9 & 70.2 & 69.0 & 763 & 787 & 771 \\
\hline
\end{tabular}

Source: Calculated on basis of Financial Statements, http://www.nbs.rs/internet/cirilica/50/50_5.html

The degree of concentration according to traditional indices is shown on table 3. Coefficients CR3 were chosen, which are used in antimonopoly practice in many countries, as well as CR4, which was often used in research works in former Yugoslavia, see (Bukvić, 1999), also in monograph (Begović et al., 2002), and finally CR8. ${ }^{3}$ The table shows also Herfindahl-Hirschman indices, since the author had access to the financial statements of all the subjects, which is not always possible in similar analyses.

Table 4. Hirschman-Herfindahl indices for chosen indicators in Serbian banking sector 2010-2018

\begin{tabular}{|l|r|r|r|r|r|r|r|r|r|}
\hline Balance variable & 2010 & 2011 & 2012 & 2013 & 2014 & 2015 & 2016 & 2017 & 2018 \\
\hline Assets & 629 & 660 & 678 & 741 & 794 & 796 & 813 & 812 & 779 \\
\hline Loans (total) & 649 & 722 & 721 & 774 & 771 & 763 & 736 & 744 & 793 \\
\hline to population & 687 & 684 & 687 & 714 & 715 & 729 & 728 & 747 & 812 \\
\hline to companies & & & & 788 & 779 & 782 & 768 & 765 & 821 \\
\hline Deposits (total) & 720 & 714 & 726 & 777 & 818 & 816 & 817 & 825 & 798 \\
\hline from population & 796 & 799 & 811 & 866 & 903 & 930 & 939 & 956 & 967 \\
\hline Income (total) & 679 & 721 & 916 & 844 & 719 & 734 & 804 & 710 & 746 \\
\hline $\begin{array}{c}\text { interest income } \\
\text { from fees and } \\
\text { commissions }\end{array}$ & 739 & 640 & 678 & 712 & 736 & 734 & 737 & 744 & 776 \\
\hline
\end{tabular}

Source: Банкарски сектор у Србији. Квартални извештај. (2010-2018)

\footnotetext{
${ }^{3}$ National bank of Serbia in its quarterly reports uses the coefficients CR5 and CR10. We will not consider the issue of whether the use of one of the CRn coefficients is justifiable in terms of its informative significance in general sense, as well as in the specific context of baking sector in Serbia.
} 
The indices of CRn and HH are also used by the National Bank of Serbia in the mentioned reviews of concentration and competition presented in the Bank's quarterly reports, earlier in Economic Overview. However, due to reasons unknown to the author of this work, they do not use the indices CR3 and CR4, which are justified from the standpoint of small markets and a small number of participant in the market, but they use indices CR5 and CR10 instead, considering share of five, i.e. ten largest banks. We deem that the use of these indices is not adequate and argumentative, and we will not consider them. Instead, we can consider the results obtained from the NBS report through the use of $\mathrm{HH}$ index (see table 4).

All index values in table 2 are less than 1,000, therefore the market should by all indicators be classified as low concentrated. This is constantly emphasized in the NBS reports. However, there is an obvious growth trend in practically all values, with a significant increase in some cases. In this sense, even if we ignore the the problem of arbitrary limits between the different market concentration types, there is hardly any room for the satisfactory report estimations that are constantly being repeated ("The banking market in Serbia is still characterized by a satisfactory level of competition and a low concentration of activity"). The paper (Miljković et al., 2013), that analyzes the period between 2008 and 2012, demonstrated a growth trend of $\mathrm{HH}$ index practically for all observed financial balances variables, with very small exceptions only in certain years and for some variables, so it can be concluded that there is an almost ten years' growth trend of $\mathrm{HH}$ indices in the Serbian banking sector.

Table 5. Degree of concentration in economy branches by the values of HHI (in antimonopoly practice in USA)

\begin{tabular}{|l|l|l|}
\hline Types of market concentration & In Guidelines 1997 & In Guidelines 2010 \\
\hline Highly concentrated markets & Above 1,800 & Above 2,500 \\
\hline Moderately concentrated markets & Between 1,000 and 1,800 & Between 1,500 and 2,500 \\
\hline Unconcentrated markets & Below 1,000 & Below 1,500 \\
\hline
\end{tabular}

Source: (Horizontal Merger Guidelines, 1997; Horizontal Merger Guidelines, 2010)

In case of both coefficients $(\mathrm{CRn}$ and $\mathrm{HH})$, the limits between different market concentration degrees are set arbitrarily. So, USA has been using $\mathrm{HH}$-indices for market classifications since 1982. Before that, the limits had been set on 1,000 and 1,800, and since 2010, they have been 1,500 and 2,500 (see Table 5). In evaluating horizontal mergers, the Agency (or Agencies, i.e. Department of Justice and the Federal Trade Commission) will consider both the post-merger market concentration and the increase in concentration resulting from the acquisitions and merger.

Table 6. Classification of industry markets based on concentration degree, which is used by the Federal Antimonopoly Service of Russia (FAS)

\begin{tabular}{|l|c|c|}
\hline Classification of industry markets & K3 concentration coefficient value & $\begin{array}{c}\text { Herfindahl-Hirschman (HHI) } \\
\text { index value }\end{array}$ \\
\hline Lowly concentrated markets & $\mathrm{K} 3 \leq 45 \%$ & $\mathrm{HHI} \leq 1,000$ \\
\hline Moderately concentrated markets & $45 \%<\mathrm{K} 3<70 \%$ & $1,000<\mathrm{HHI}<2,000$ \\
\hline Highly concentrated markets & $\mathrm{K} 3>70 \%$ & $\mathrm{HHI}>2,000$ \\
\hline
\end{tabular}

Source: (Федеральная антимонопольная служба, 2016) 
The antimonopoly authority in Russia (Federal Antimonopoly Service of Russia, FAS) uses simultaneously both indices, $\mathrm{CR}$ and $\mathrm{HH}$. The limits for the three types of market concentration are $45 \%$ and $70 \%$ for $\mathrm{CR} 3$, and 1,000 and 2,000 for $\mathrm{HH}$, that separate lowly, moderately, and highly concentrated markets (see Table 6). The values of $\mathrm{HH}$ indices for all variants in our analysis are less than 1,000, so the market should be classified as lowly concentrated. On the other hand, according to the CR3 index, it also belongs to non-concentrated markets, but if were to use the CR4 index, we would have to classify the market as a moderately concentrated one (except for the third variant, the capital, but in that case, the value of CR4 is practically on the limit between a nonconcentrated and a moderately-concentrated market).

Table 7. The degree of concentration in economy sectors based on the $\mathrm{HH}$ index values (modified classification):

\begin{tabular}{|l|l|}
\hline Degree of concentration & Values of HHI \\
\hline Absolutely concentrated & 10,000 \\
\hline Extra concentrated & From 2,600 to 10,000 \\
\hline Highly concentrated & From 1,800 to 2,600 \\
\hline Moderately concentrated & From 1,000 to 1,800 \\
\hline Unconcentrated markets & Below 1,000 \\
\hline
\end{tabular}

Source: (Begović et al., 2002)

Clearly, other possible limits between lowly, moderately and highly concentrated markets could result in a different classification. This is one of the main flaws of the $\mathrm{CRn}$ and $\mathrm{HH}$ index use. Therefore, other approaches to researching concentration and competition are also necessary. Considering the conditions and circumstances of Serbian economy (smaller overall market, fewer producers across industries, etc.), it is evident that such market classification according to the concentration degrees is inadequate (in almost every industry HHI values would be in the second group), therefore it is possible and desirable to make the necessary and useful modifications to table 5. One such successful attempt was made in the monograph [Begović et al. 2002]. (See Table 7.)

Obviously, the indices from tables 3 and 4 show different tendencies through the times. It is, therefore, useful to examine the concentration by using some other indicators. In such analyses, the researchers use also the Gini coefficients and Lorenz curve. So, we shaped the Lorenz curve (see figure 2), for the V1, i.e. total assets in 2018. After them, we calculated these (Gini) indices for observed five variables, for the 2016 and 2018. The results are shown on table 8 . 


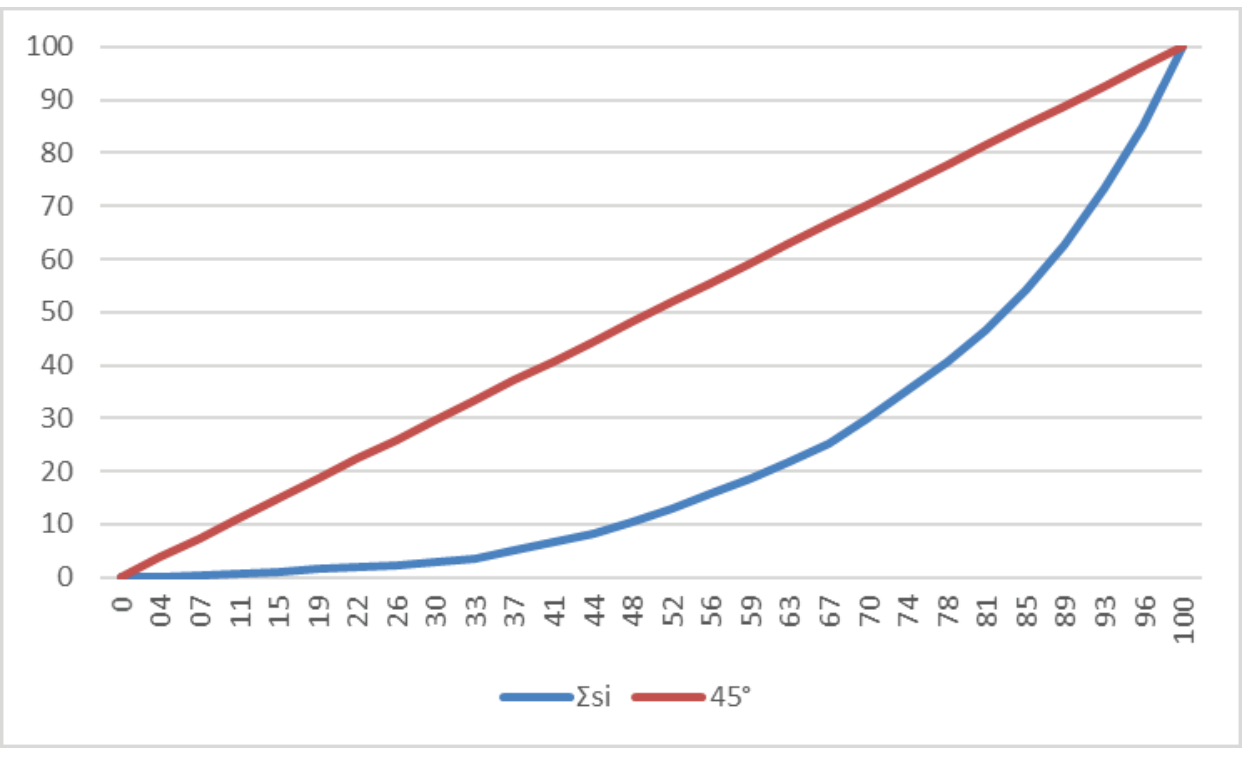

Figure 2. Lorenz curve for the variable total assets in 2018

Source: Calculated on basis of Financial Statements, http://www.nbs.rs/internet/cirilica/50/50_5.html

As we can see, Gini coefficients for all five variables increased from 2016 to 2018. This shows (undoubtedly?) that the concentration in 2018 is greater than in 2016 (see Table 8 ). It may be an opposite result compared with the results from the use of coefficients CRn and HH. On the other hand, both Lorenz curve and Gini coefficient show the same problem that exists in the standard coefficients CRn and HHI. It is, namely, necessary to set limits in advance, which will help classify certain empirically calculated concentration degree as high, moderate or low or according to another generally accepted concentration degree scale.

Table 8. Gini coefficients for the observed indicators in 2016 and 2018

\begin{tabular}{|l|c|c|}
\hline & 2016 & 2018 \\
\hline Total assets & 0.5681 & 0.5808 \\
\hline Deposits and other liabilities & 0.5722 & 0.5856 \\
\hline Capital & 0.5833 & 0.5935 \\
\hline Operating income & 0.5489 & 0.5855 \\
\hline Loans and receivables & 0.5544 & 0.5719 \\
\hline
\end{tabular}

Source: Calculated on basis of Financial Statements, http://www.nbs.rs/internet/cirilica/50/50_5.html

This is, also, the one more reason to further research, i. e. for the use of other methods.

One of them are Linda-indices. Unlike the previously mentioned ones, Lindaindices are meant to reveal the existence of oligopoly structures without using any arbitrarily established limits. In contrast, the index values indicate whether oligopoly is present or not in a given market. In the case of a competitive market, the index value decreases $\left(\mathrm{IL}_{\mathrm{m}+1}>\mathrm{IL}_{\mathrm{m}}\right.$ for all $\left.\mathrm{m}\right)$. If this pattern is broken, it indicates that there is an 
oligopoly situation in a given market. In our case, only the third variant points out to the existence of oligopoly, which are the Linda-indices calculated on the basis of the capital value (see Table 9). Besides the Linda-indices (V1, V2, V3, V4, and V5, for five values in Table 9), it also shows the column (PE). It represents the so-called perfect equilibrium curve, which is the situation of perfect equality among the participants in a marketplace. The shares of such perfect competitors are the same one to another, and equal to the value $1 / \mathrm{n}(\mathrm{n}=$ number of participants in market).

Table 9. Linda indices for selected variables in Serbian banking sector in 2016, 2017 and 2018

\begin{tabular}{|l|c|c|c|c|c|c|c|c|c|c|c|c|c|c|c|c|}
\hline Year & \multicolumn{9}{|c|}{2016} & \multicolumn{7}{|c|}{2017} \\
\hline IL & V1 & V2 & V3 & V4 & V5 & V1 & V2 & V3 & V4 & V5 & V1 & V2 & V3 & V4 & V5 & PE \\
\hline & & & & & & & & & & & & & & & & 1 \\
\hline IL2 & 0.69 & 0.63 & 0.97 & 0.76 & 0.70 & 0.77 & 0.72 & 0.86 & 0.85 & 0.68 & 0.65 & 0.64 & 0.68 & 0.83 & 0.67 & 0.500 \\
\hline IL3 & 0.49 & 0.48 & 0.62 & 0.51 & 0.48 & 0.47 & 0.46 & 0.55 & 0.52 & 0.47 & 0.44 & 0,43 & 0.47 & 0.52 & 0.47 & 0.333 \\
\hline IL4 & 0.42 & 0.41 & 0.44 & 0.41 & 0.38 & 0.38 & 0.37 & 0.39 & 0.38 & 0.37 & 0.36 & 0.37 & 0.37 & 0.38 & 0.39 & 0.250 \\
\hline IL5 & 0.35 & 0.35 & 0.34 & 0.32 & 0.32 & 0.32 & 0.31 & 0.31 & 0.30 & 0.32 & 0.31 & 0.31 & 0.30 & 0.31 & 0.34 & 0.200 \\
\hline IL6 & 0.32 & 0.33 & 0.28 & 0.29 & 0.30 & 0.29 & 0.30 & 0.27 & 0.25 & 0.29 & 0.29 & 0.27 & 0.25 & 0.30 & 0.30 & 0.167 \\
\hline IL7 & 0.30 & 0.30 & 0.25 & 0.27 & 0.28 & 0.28 & 0.28 & 0.25 & 0.24 & 0.26 & 0.26 & 0.25 & 0.23 & 0.27 & 0.27 & 0.143 \\
\hline IL8 & 0.27 & 0.27 & 0.27 & 0.25 & 0.25 & 0.26 & 0.26 & 0.25 & 0.24 & 0.24 & 0.23 & 0.23 & 0.24 & 0.25 & 0.23 & 0.125 \\
\hline IL9 & 0.25 & 0.25 & 0.27 & 0.23 & 0.24 & 0.24 & 0.24 & 0.25 & 0.22 & 0.23 & 0.22 & 0.23 & 0.24 & 0.22 & 0.23 & 0.111 \\
\hline IL10 & 0.21 & 0.21 & 0.23 & 0.20 & 0.20 & 0.20 & 0.20 & 0.21 & 0.19 & 0.20 & 0.19 & 0.19 & 0.20 & 0.19 & 0.19 & 0.100 \\
\hline
\end{tabular}

Source: Обрачун на основу Financial Statements, http://www.nbs.rs/internet/cirilica/50/50_5.

html

The third variant (variable V3, i.e. capital) indicates the existence of oligopoly (IL8>IL7) in all three years: the sequence of indices ILi is not monotonically decreasing function. However, the observed variable (capital), as residual of assets and liabilities, is the "worst quality" variable among the chosen ones. Therefore, having taken into consideration the other results from Table 5, it could be said with great certainty that the results obtained by coefficients CR3, CR4 and $\mathrm{HH}$ were confirmed, i.e. that the Serbian banking sector in analyzed years is lowly concentrated. And this is the good foundation for competition development. 
Figure 3. Linda indices for capital and "perfect equilibrium" curve for banking sector, Serbia 2018

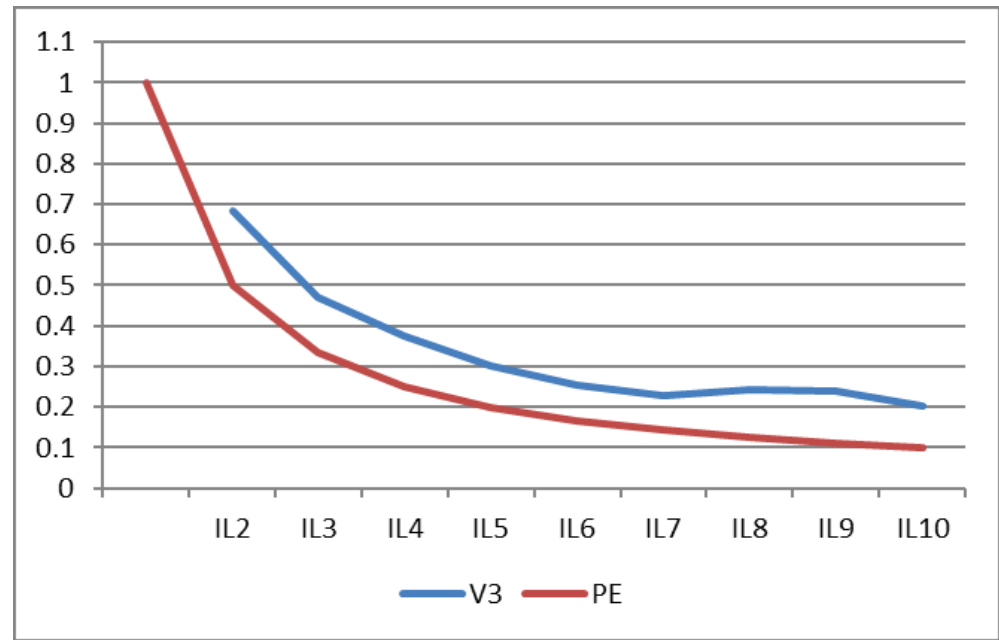

Source: On the base of Financial Statements, http://www.nbs.rs/internet/cirilica/50/50_5.html

The graphical representation of Linda-index is also of great interest (see Figure 3). It shows indices for capital, where, as shown in Table 3, there is a suspicion of oligopolistic structures. Unlike the indices $\mathrm{CRn}$, which are a monotonically increasing function as each next participant is added $(\mathrm{CR} 1<\mathrm{CR} 2<\ldots<\mathrm{CRn})$, Linda indices form a broken curve (Figure $3)$. The area between IL and PE is named "oligopolistic arena" and it even visually shows the difference between the real situation and an ideal, perfect competition.

Figure 4. The shares of leading banks in total banking sector capital in 2018

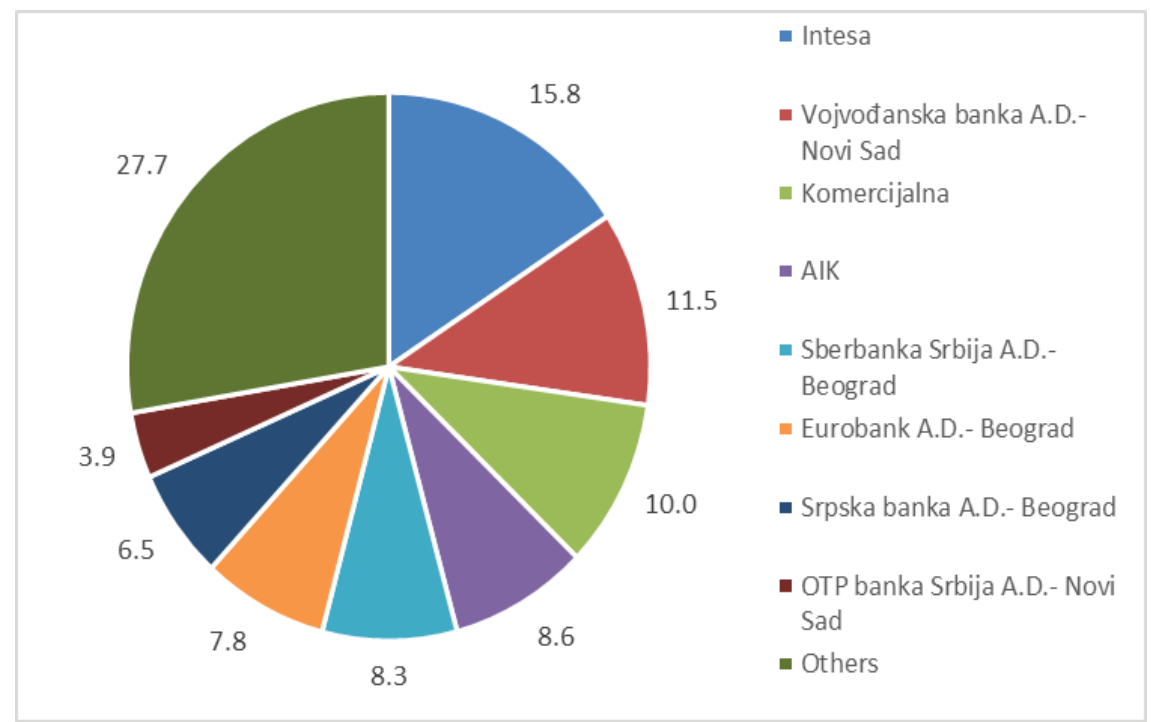

Source: On the base of Financial Statements, http://www.nbs.rs/internet/cirilica/50/50_5.html 
The bank shares in the total banking sector capital are shown on Figure 4. They suggest, that the first seven banks form an oligopolistic structure - the seventh one in range (Srpska banka) is greater by over $68 \%$ in terms of capital than the next, eighth one (OTP banka) (the shares are $6.5: 3.9$ ). If so, of course, this could be a case of so-called loose oligopoly, in which, by theoretical propositions, 6-7 firms participate in a market with a $70-80 \%$ share. In our case, this share for the first seven firms in 2018 is $68.4 \%$, very close to down limit of theoretical loose oligopoly. Therefore, such a conclusion can be drawn. The state of the banking market must be permanently observed, because the values of coefficients $\mathrm{HH}$, even CR4 are close to being moderately concentrated. As shown previously, the National Bank of Serbia does so, although through the use of simple instruments.

\section{Conclusion}

In spite of the many years long decreasing trend in the number of banks, banking market in Serbia is still characterized by a relatively large number of banks (27). Among them there are no prominently large banks. According to all the chosen indicators (total assets, deposits, capital, operating income, and loans), the greatest share is held by the Intesa Bank $15.1 ; 15.1 ; 15.8 ; 17.1$ and $15.7 \%$, respectively. These results are somewhat lower than in 2016 (16.4; 19.6; 16.6; 17.0 and 15.8\%, respectively). The concentration indices (CR3, CR4, $\mathrm{HH}, \mathrm{G}$ and Linda indices IL) indicate a low concentration degree, although close to being moderately concentrated, but also an absence of oligopoly, with the mentioned exception by the results of capital. Even though this does not assume the existence of true competition, these results point out to good perspectives for creation and development of competition. In fact, we could consider that our results confirm the results obtained by (Lončar \& Rajić, 2012) and (Miljković et al., 2013), which referred to three quarters of 2012, as well as those of (Ljumović et al., 2014), for the period between 2003 and 2012. However, we should take account of a slight growth in concentration. It is difficult to compare the results of these works due to the differing approaches that were used, although the application of the HH index is a solid foundation for comparison in such cases.

Concentration in the banking sector can have many implications, namely on the competitiveness and efficiency (not only in the banking sector). Therefore, it is important on one hand that regulatory bodies follow the concentration degree trends, especially since in the future the trend of merges and acquisitions can be expected to increase. On the other hand, it is necessary to thoroughly observe and analyze the competition in the banking sector, which should by no means be limited only to the concentration degree. As banking competition is very complex, this paper should be considered as one of the first analyses of concentration and competition in Serbian banking, and in the Serbian financial market in general. We emphasize that this research continues our deal with concentration and competition in Serbian banking sector. However, we hope that it will be a research subject of other researchers. New approaches would, naturally, be desirable in such future researches. On the other side, of some interest may be the comparative analysis of the concentration and competition in Serbian and banking sector of the neighbouring countries, as well the other former socialist countries, by more indicators than in (Barjaktarović et al., 2013). 
In addition to the fact that the concentration degree is not high despite its increase through many years, more attention should be put towards the actions of banks in the market, which falls under the scope of regulation and control. In particular, the issues of collusion and deals between banks should be dealt with, although they have not been considered in this paper.

\section{References}

Alihodžić, Almir (2019). Tržišna koncentracija banaka i nezaposlenost: Evidencija na tržištu banaka Bosne i Hercegovine i Srbije, Bankarstvo, 48(2), 32-59.

Bankarski sektor SRJ 31.12.2001.g. (2000) Beograd: Narodna banka Jugoslavije.

Barjaktarović, Lidija i Dejan Ječmenica (2011). Optimizam vs pesimizam konkurentnosti bankarskog sektora Srbije, Industrija, 39(2), 137-150.

Barjaktarović, Lidija; Sanja Filipović, Maja Dimić (2013). Concentration Level of the Banking Industry in CEE Countries, Industrija, 41(3), 39-54.

Baumol, William J. (1982). Contestable Markets: An Uprising in the Theory of Industry Structure, The American Economic Review, 72 (1), 1-15.

Begović, Boris; Rajko Bukvić, Boško Mijatović, Marko Paunović, Robert Sepi \& Dragor Hiber (2002). Competition Policy in FR Yugoslavia - Existing Market Structures and Competition Institutions, Belgrade: Center for Liberal-democratic Studies.

Berger, Allen N.; Rebecca S.Demsetz, Philip E. Strahan (1999). The consolidation of the financial services industry: Causes, consequences, and implications for the future, Journal of Banking \& Finance, 23 (2-4), 135-194.

Berger, Allen N. \& T.H. Hannan (1989). The Price-Concentration Relationship in Banking, The Review of Economics and Statistics, 71 (2), 291-299.

Bikker, Jacob A. \& Katharina Haaf (2002a). Competition, concentration and their relationship: An empirical analysis of the banking industry, Journal of Banking \& Finance, 26 (11), 2191-2214.

Bikker, Jacob A. \& Katharina Haaf (2002b). Measures of Competition and Concentration in the Banking Industry: a Review of the Literature, Economic \& Financial Modelling, 9 (2), 53-98.

Bukvić, Rajko (1999). Istraživanja tržišnih struktura u privredi druge Jugoslavije, Ekonomika, 35 (1), 4-16. /Researches of the Market Structures in the Economy of the Former Yugoslavia, Ekonomika, 35 (1), 4-16./

Bukvić, Rajko M. (2017). Concentration and Competition in Serbian Banking Sector, The Scientific Journal of Cahul State University "Bogdan Petriceicu Hasdeu”: Economic and Engineering Studies, 2(2), 4-12.

Bukvić, Rajko M. (2019). Evolution and Current State of the Competitive Environment in Serbian Banking Sector: Concentration Indices Analysis, In: Igor Janev (ed.) Serbia: Current Political, Economic and Social Issues and Challenges, Nova Science Publishers, Inc., New York, 23-42. 
Collender, Robert N. and Sherrill L. Shaffer (2000). Local bank office ownership, deposit control, market structure, and economic growth, Technical bulletin of U.S. Department of Agriculture, № 1886.

Eraković, Eva (2017). Concentration Effect on the Efficiency Banking Sector in the Republic of Serbia, Facta Universitatis Series: Economics and Organization, 14(3), 281-289.

Hannan, Timothy H. (1991). Foundations of the Structure-Conduct-Performance Paradigm in Banking, Journal of Money, Credit and Banking, 23(1), 68-84.

Horizontal Merger Guidelines, U.S. Department of Justice and the Federal Trade Commission, Issued: April 2, 1992, Revised: April 8, 1997. www.justice.gov/atr/ public/guidelines/hmg.pdf

Horizontal Merger Guidelines, U.S. Department of Justice and the Federal Trade Commission, Issued: August 19, 2010. www.justice.gov/atr/public/guidelines/ hmg-2010.pdf

Jayaratne, Jith \& Philip E. Strahan (1996). The Finance Growth Nexus: Evidence from Bank Branch Deregulation, Quarterly Journal of Economics, 111(3), 639-670.

Khemani, R. Shyam \& Daniel M. Shapiro (compiled by) (1993). Glossary of Industrial Organisation Economics and Competition Law, commissioned by the Directorate for Financial, Fiscal and Enterprise Affairs, OECD.

Linda, Rémo (1976). Methodology of concentration analysis applied to the study of industries and markets, Brussels: Commission of the European Communities.

Lipczynski, John; John O.S. Wilson, John Goddard (2017). Industrial Organization. Competition, Strategy and Policy, Pearson Education Limited, Harlow.

Ljumović, Isidora; Vladan Pavlović, Janko M. Cvijanović (2014). Two Aspects of Concentration in Serbian Banking Sector, Industrija, 42 (3), 61-77.

Lončar, Dragan \& Vesna Rajić (2012). Concentration and Competitiveness of Banking Market in Serbia: Current Situation and Possible Future Changes under the Influence of Market Consolidation, Ekonomika preduzeća, 60 (7-8), 372-385.

Maksimović, Ljiljana i Kostić Milan (2012). Limitations in the Application of Concentration Indicators, Ekonomika preduzeća, 60(3-4), 199-205.

Martić, Ljubomir (1986). Mjere nejednakosti i siromaštva, Zagreb: Brotehnika. / Inequality and Poverty Measures, Zagreb: Birotehnika, 1986./

Miljković, Marko; Sanja Filipović, Svetozar Tanasković (2013). Market Concentration in the Banking Sector - Evidence from Serbia, Industrija, 41 (2), 7-25.

Miller, Roger Leroy \& David D. Vanhoose (1993). Modern money and banking, 3rd ed., New York: McGraw-Hill.

Northcott, Carol Ann (2004). Competition in Banking, Financial System Review, 6, June, 75-77.

Petersen, Mitchell A. and Raghuram G. Rajan (1995). The effect of credit market competition on lending relationship, Quarterly Journal of Economics, 110(2), 407-443.

Rajan, Raghuram G. \& Luigi Zingales (2003). Banks and Markets: The Changing Character of European Finance, NBER Working Paper 9595, Cambridge. 
Rybczynski, Tad M. (1997). A New Look at the Evolution of the Financial System, in Revell, Jack (ed.) The Recent Evolution of Financial Systems, London: Macmillan, 3-15.

Shaffer, Sherrill L. (1998). The winner's curse in banking, Journal of Financial Intermediation, 7(4). 359-392.

Smirlock, Michael (1985). Evidence on the (Non) Relationship between Concentration and Profitability in Banking, Journal of Money, Credit and Banking, 17 (1), 69-83.

Vuković, Vlastimir. Tržišna koncentracija domaćih banaka, Finansije, godina 61, № 1-6, 2006, str. 5-17.

World Development Report 1996 (1996). New York: Oxford University Press.

Банкарски сектор 2002 (2002). Београд: Народна банка Србије. /Banking sector 2002, Belgrade: National Bank of Serbia./

Банкарски сектор у Србији. Квартални извештај. (2010-2018) Београд: Народна банка Србије. /Banking Sector in Serbia. Quarterly Report. (2010 2018) Belgrade: National Bank of Serbia./

Биланс стања/успеха банака, Београд: Народна банка Србије, 2016, 2017, 2018. / Financial Statements/ http://www.nbs.rs/internet/cirilica/50/50_5.html

Буквић, Рајко M. (2017). Концентрација и конкуренција у банковном сектору Србије, XLIV Simpozijum o operacionim istraživanjima, SYM-OP-IS 2017 Zlatibor 25-28 septembar 2017, Zbornik radova, ur. Goran Ćirović, Visoka građevinsko-geodetska škola, Beograd, стр. 472-477. /Bukvić, Rajko M. (2017) Concentration and Competition in Serbian Banking Sector, XLIV Szmposium n Operations Research, SYM-OP-IS Zlatibor 25-28 September 2017, Proceedings, ed. Goran Ćirović, Visoka građevinsko-geodetska škola, Belgrade, pp. 472-477./

Буквич, Райко (2013). Исследование рыночных структур: индекс концентрации Линда, Проблемы теории и практики управления, (10), 49-55. /Bukvić, Rajko. (2013) Research of Market Structure: concentration index Linda, Problems of the Theory and Practice of Management, (10), 49-55./

Буквич, Райко (2015). Рынок: конкуренция и монополия, Княгинино: Нижегородский государственный инженерно-экономический университет. /Bukvić, Rajko (2015) Market: Competition and Monopoly, Knyaginino: Nizhny Novgorod State University of Engineering and Economics./

Коробова, Галина Григорьевна (ред.) (2006). Банковское дело, Москва: Экономистъ. /Korobova, Galina Grigorevna (red.) (2006) Banking, Moscow: Ekonomist./

Костић, Милан Т. (2013). Тржищна моћ корпоращија и конкуренција у грани, докторска дисертација, Крагујевац: Економски факултет. /Kostić, Milan T. (2013). Market Power of Corporations and Competition in the Branch, Doctoral Dissertation, Kragujevac: Faculty of Economics./

Коцофана, Татьяна Викторовна и Полина Сергеевна Стажкова (2011). Сравнительный анализ применения показателей концентрации на примере банковского сектора РФ, Вестник Санкт-Петербургского Государственного Университета. Серия Экономика, (4), 30-40. /Kotsofana, 
Tatyana Viktorovna \& Polina Sergeevna Stazhkova (2011) Comparative analysis of the use of concentration indicators on the example of banking sector of RF, Vestnik of Sankt-Petersburg State University. Series Economics, (4), 30-40./

Маринковић, Срђан (2007). Стање и динамика степена концентрације у банкарском сектору Србије, Теме, 31(2), 283-299. /Marinković, Srđan (2007). The Industrial Concentration in Serbian Banking: The Degree and Its Dynamics, Teme, 31(2), 283-299.

Моисеев, Сергей Рустамович (2008). Эффекты банковской концентрации, Современная конкуренция, 1(7), 103-112. /Moiseev, Sergey Rustamovich (2008). Effects of banking concentration, Modern Competition, 1(7), 103-112./

Ракша, Александр Денисович (2010). Конкуренция в банковской сфере, Банковское дело, (11), 25-27. /Raksha, Alexander Denisovich (2010) Competition in Banking Sphere, Banking, (11), 25-27./

Федеральная антимонопольная служба (2016). Об утверждении Порядка проведения анализа состояния конкуренции на товарном рынке (с изменениями на 20 июля 2016 года) от 28 апреля 2010 года N 220, http:/ docs.cntd.ru/document/902215421/Federal Antimonopoly Service. On approval of the analysis of the state of competition in the commodity market (as amended on July 20, 2016)./

\section{Endnotes}

1. In addition to the four mentioned banks, which were stripped of operating licence in 2002, Marinkovic cites examples of three such cases in the first half of the 2010's: Raj Bank Belgrade, Credit-Export Banks Belgrade and MB Bank Nis (Маринковић, 2007, p. 284).

2. For the theoretical backgrounds of the S-C-P paradigm see for example: (Hannan, 1991).

3. A review of literature about the use of concentration measures in banking sector until the beginning of 2000s is given in (Bikker \& Haaf, 2002b).

4. Except are my own articles: (Bukvić, 2017), (Bukvić, 2019), (Буквић, 2017). All three refer to banking sector. 